\title{
Rib Somatic Dysfunction Among General Surgical Patients
}

Gerard A. Baltazar, DO; Christine E. Kolwitz, DO; Michael G. Florek, DO

From the City University of New York School of Medicine in New York (Dr Baltazar); the College of Osteopathic Medicine at New York Institute of Technology in Old Westbury (Dr Baltazar); the Department of Surgery (Drs Baltazar and Kolwitz) and the Department of

Osteopathic Manipulative Medicine and Neuromuscular Medicine at St Barnabas Hospital Health System in Bronx, New York (Dr Florek); and the Department of Surgery at New York University Winthrop Hospital in Mineola (Dr Baltazar).

Financial Disclosures: None reported.

Submitted: None reported. Address correspondence to Gerard A. Baltazar, DO, Department of Surgery at New York University Winthrop Hospital, 222 Station Plaza North, Ste 603, Mineola, NY 11501-3893.

Email: gerard.baltazar@nyulangone. org

Submitted March 5, 2019; revision received September 27, 2019; accepted October 24, 2019.
Context: Upper abdominal or chest pain, tenderness, or sensation of the presence of a mass may lead to general surgery (GS) service referral. These symptoms may be related to rib somatic dysfunction $(\mathrm{SD})$.

Objective: To describe rib SD in the GS setting and help build a foundation for additional osteopathic manipulative treatment (OMT) research in surgical care.

Methods: The authors retrospectively reviewed and analyzed the electronic medical records of patient encounters in a GS outpatient clinic or private office in Bronx, New York. Included patients had emergency department or inpatient GS consultations with the diagnosis of rib SD (ICD-9 739.8 or ICD-10 M99.08) initially made by the GS service from February 1, 2016, to January 31, 2019. Six-month followup data were also reviewed.

Results: Twelve patients had rib SD as the underlying cause of their chief concern upon presentation to the GS service. Only 1 also had an underlying operative GS disease. The GS service treated 11 patients $(91.7 \%)$ with OMT; 1 patient refused OMT. Time spent on OMT ranged from 5 to 30 minutes, with a median of 10 minutes and a mean (SD) of 12.7 (9.05) minutes. The OMT techniques used included balanced ligamentous tension, counterstrain, muscle energy, myofascial release, rib-raising, and soft tissue. All patients who received OMT demonstrated improvement, and 3 patients required osteopathic manipulative medicine/neuromuscular medicine follow-up.

Conclusions: Rib somatic dysfunction may contribute to patient referral to a GS service, and OMT performed by general surgeons may help provide optimal surgical care.

J Am Osteopath Assoc. 2020;120(9):590-596. Published online August 7, 2020. doi:10.7556/jaoa.2020.097

Keywords: general surgery, osteopathic manipulative treatment, rib somatic dysfunction 
Rib somatic dysfunction (SD) is a relatively common ailment, also with limited data available in the scientific literature. $^{3-6}$ In the Consortium for Collaborative Osteopathic Research Development Practice-Based Research Network multicenter study of outpatient clinics, Licciardone et $\mathrm{al}^{6}$ found that OMT for rib SD was performed for 357 adult patients $(74.8 \%, n=477)$, 10 pediatric patients $(50 \%, \mathrm{n}=20)$, and 144 geriatric patients $(84.2 \%, \mathrm{n}=171)$. These data suggest that OMT for rib SD is common in the outpatient setting.

This study aims to describe our GS experience with rib SD in both inpatient and outpatient cases to help build a foundation for additional OMT research in the context of surgical care.

\section{Methods}

The institutional review board at St Barnabas Hospital (SBH) Health System approved this study in February 2019. SBH is an American College of Surgeons-verified level II, 350-bed trauma center. The general surgeons at SBH cover GS, acute care surgery, trauma surgery, and surgical critical care and treat patients in urban, underserved outpatient and inpatient settings. SBH operates GS and osteopathic manipulative medicine/neuromuscular medicine (OMM/NMM) residency programs.

Anecdotal GS data suggested that a recurrent reason for OMT in the GS setting was rib SD. We retrospectively reviewed the electronic medical records (EMRs) of patients at SBH who had International Statistical Classification of Diseases and Related Health Problems-9 or -10 codes for rib SD (739.8 and M99.08, respectively) as part of their EMRs from February 1, 2016 to January 31, 2019. We reviewed progress notes and included patients who were initially diagnosed by the GS service with these codes. There were no exclusions.

At $\mathrm{SBH}$, the OMM/NMM service is routinely consulted for admitted general surgical patients a priori diagnosis of SD, and whole-body OMT is routinely performed by this service, including for rib SD. All
OMT described in this study was performed by or under the supervision of one of the authors (G.B.).

We reviewed demographic data, chief concerns, patient histories, physical examinations, laboratory and imaging test results, assessments, and treatment plans, including operations performed. We also reviewed any outpatient or inpatient follow-up data available in the EMRs up to 6 months after each patient's first contact with the GS service. The EMRs from the emergency department, inpatient, and hospital service clinic settings were retrieved from a single EMR system that is specific to the SBH health system. The EMRs from the private office setting were retrieved from a separate EMR to which the authors had full access. A multiinstitutional online EMR system (BronxRHIO) was also reviewed for patient records. We organized our data as a descriptive study of a known diagnosis in a novel setting. All statistical analyses were performed with Excel for Macintosh (version 15.32; Microsoft).

\section{Results}

Twelve patients were diagnosed with rib SD by the GS service. Eight patients (67\%) were women, and 4 were men (33\%). Patient ages ranged from 20 to 68 years (median, 52 years; mean [SD], 48.6 [14.2] years).

Patients encountered the GS service in multiple settings: $2(16.7 \%)$ in a private office, $3(25 \%)$ as inpatient consultation, $6(50 \%)$ in a hospital service clinic, and 1 $(8.3 \%)$ as emergency department consultation (Table 1). Unilateral symptoms were most often reported among patients with chief concerns of pain or mass sensation on the side of the chest, upper abdomen, or flank. A full list of chief concerns is found in Table 1. One patient had the chief concerns of centralized upper abdominal or epigastric pain that favored the left side.

Two patients had previous operations that were directly associated with their chief concerns: 1 had leftsided thoracoabdominal pain and mass sensation after remote left video-assisted thoracoscopic surgery, and 1 had right-sided chest pain after a right breast mass 
Table 1.

Patient Encounters With OMT and the GS Service at St Barnabas Hospital Health System Between February 1, 2016 to January 31, $2019(\mathrm{~N}=12)$

\begin{tabular}{|c|c|c|c|c|c|c|c|c|}
\hline Patient & $\begin{array}{l}\text { Encounter } \\
\text { location }\end{array}$ & $\begin{array}{l}\text { Preencounter } \\
\text { chief concerns }\end{array}$ & $\begin{array}{c}\text { Procedure } \\
\text { (s) }\end{array}$ & Imaging results & $\begin{array}{c}\text { GS } \\
\text { diagnosis }\end{array}$ & $\begin{array}{c}\text { OMT } \\
\text { performed } \\
\text { (outcome) }\end{array}$ & $\begin{array}{c}\text { Prescribed } \\
\text { pain } \\
\text { medications }\end{array}$ & $\begin{array}{c}\text { Postencounter } \\
\text { procedure(s) }\end{array}$ \\
\hline 1 & OFFICE & RUQ painful mass & None & $\begin{array}{c}\text { AP CT (no } \\
\text { abdominopelvic } \\
\text { pathology) }\end{array}$ & None & $\begin{array}{l}\text { Yes (P\&T } \\
\text { resolved, mass } \\
\text { sensation } \\
\text { resolved) }\end{array}$ & None & None \\
\hline 2 & OFFICE & LUQ pain & None & None & None & $\begin{array}{l}\text { Yes (P\&T } \\
\text { resolved, } \\
\text { Improved } \\
\text { AROM) }\end{array}$ & None & None \\
\hline 3 & INPATIENT & $\begin{array}{l}\text { RUQ and rib pain } \\
\text { and mass }\end{array}$ & None & $\begin{array}{c}\text { Abdominal US } \\
\text { (acute cholecystitis) }\end{array}$ & $\begin{array}{c}\text { Acute } \\
\text { cholecystitis }\end{array}$ & $\begin{array}{c}\text { Yes }(P \& T \text { T/10 } \rightarrow \\
\text { 1/10, mass } \\
\text { sensation } \\
\text { resolved, } \\
\text { improved AROM) }\end{array}$ & $\begin{array}{l}\text { APAP, } \\
\text { Oxycodone, and } \\
\text { lbuprofen }\end{array}$ & $\begin{array}{l}\text { Laparoscopic } \\
\text { cholecystectomy } \\
\text { and ERCP }\end{array}$ \\
\hline 4 & CLINIC & $\begin{array}{c}\text { LUQ and left } \\
\text { chest painful mass }\end{array}$ & $\begin{array}{l}\text { Left VATS } \\
\text { with lung } \\
\text { biopsy }\end{array}$ & $\begin{array}{c}\text { CAP CT } \\
\text { (cholelithiasis, } \\
\text { umbilical hernia, no } \\
\text { thoracic pathology) }\end{array}$ & None & $\begin{array}{c}\text { Yes }(\text { P\&T } 8 / 10 \rightarrow \\
\text { 2/10, improved } \\
\text { AROM) }\end{array}$ & None & None \\
\hline 5 & CLINIC & Left flank pain & None & $\begin{array}{l}\text { Abdominal US } \\
\text { (cholelithiasis) }\end{array}$ & $\begin{array}{l}\text { Asymptomatic } \\
\text { cholelithiasis }\end{array}$ & $\begin{array}{l}\text { Yes (P\&T } \\
\text { resolved) }\end{array}$ & None & None \\
\hline 6 & CLINIC & Right chest pain & $\begin{array}{l}\text { Right breast } \\
\text { mass } \\
\text { excision }\end{array}$ & None & $\begin{array}{l}\text { Perioperative } \\
\text { hematoma }\end{array}$ & $\begin{array}{c}\text { Yes (P\&T 10/10 } \\
\rightarrow 7 / 10, \text { improved } \\
\text { AROM) }\end{array}$ & $\begin{array}{l}\text { APAP, } \\
\text { Oxycodone, and } \\
\text { Ibuprofen }\end{array}$ & None \\
\hline 7 & INPATIENT & RUQ pain & None & $\begin{array}{l}\text { Abdominal US } \\
\text { (cholelithiasis) }\end{array}$ & $\begin{array}{l}\text { Asymptomatic } \\
\text { cholelithiasis }\end{array}$ & $\begin{array}{c}\text { Yes (P\&T 10/10 } \\
\rightarrow 3 / 10, \text { improved } \\
\text { AROM) }\end{array}$ & None & None \\
\hline 8 & ED & $\begin{array}{l}\text { RUQ \& right chest } \\
\text { pain }\end{array}$ & None & $\begin{array}{l}\text { Abdominal US (no } \\
\text { abdominal } \\
\text { pathology) }\end{array}$ & None & $\begin{array}{c}\text { Yes (P\&T 10/10 } \\
\rightarrow 6 / 10, \text { improved } \\
\text { AROM) }\end{array}$ & Ibuprofen & None \\
\hline 9 & CLINIC & LUQ mass & None & None & None & No (refused) & None & None \\
\hline 10 & INPATIENT & LUQ pain & None & $\begin{array}{c}\text { CAP CT } \\
\text { (pneumonia) }\end{array}$ & None & $\begin{array}{c}\text { Yes (P\&T 10/10 } \\
\rightarrow 5 / 10, \text { improved } \\
\text { AROM) }\end{array}$ & None & None \\
\hline 11 & CLINIC & Rib pain & None & $\begin{array}{c}\mathrm{CXR} / \text { rib series } \\
\text { (healed rib fractures) }\end{array}$ & Rib fractures & $\begin{array}{c}\text { Yes (P\&T } \\
\text { resolved, } \\
\text { improved AROM) }\end{array}$ & None & None \\
\hline 12 & CLINIC & Epigastric pain & None & $\begin{array}{c}\text { AP CT (remote } \\
\text { cholecystectomy) }\end{array}$ & None & $\begin{array}{c}\text { Yes (P\&T 10/10 } \\
\rightarrow 4 / 10, \text { improved } \\
\text { AROM) }\end{array}$ & None & None \\
\hline
\end{tabular}

Abbreviations: AROM, active range of motion; APAP, acetaminophen; CAP, chest/abdomen/pelvis; CLINIC, hospital service clinic; CT, computed tomography; CXR, chest roentgenogram; ED, emergency department consultation; ERCP, endoscopic retrograde cholangiopancreatography; GS, general surgery; INPATIENT, inpatient consultation; LUQ, left upper quadrant; OFFICE, private office; P\&T, pain and tenderness; RUQ, right upper quadrant; US, ultrasonography; VATS, video-assisted thorascopic surgery.

excision and subsequent perioperative hematoma. All patients were referred from a primary care physician to the GS service except the patient who had the breast mass excision and was referred by her breast surgeon. Nine patients $(75 \%)$ had preencounter imaging. Eight of the preencounter images evaluated the abdomen, 
and 1 image evaluated the chest for rib pain. While images for 3 of the patients revealed cholelithiasis without cholecystitis, which was described as a partial impetus for GS consultation, only 1 of these patients had any right-sided concerns. No patient received postencounter imaging.

One patient with a chief concerns of right-sided thoracoabdominal pain and imaging consistent with acute calculous cholecystitis underwent cholecystectomy. No other patients required postencounter operations.

Eleven patients $(91.7 \%)$ received OMT from the GS service; 1 patient refused pending planned computed tomography, which the patient later also refused. Each patient receiving OMT had improvement in their chief concerns of pain and tenderness (P\&T), and 9 patients $(81.8 \%)$ also reported an improved active range of motion. P\&T completely resolved in 4 patients (36.4\%) who received OMT from the GS service. Among patients whose P\&T did not resolve, the mean (SD) immediate post-OMT improvement in selfreported ordinal pain scale was 5.14 (1.35) points on a scale from 0 to 10 .

After GS service encounter and OMT, mass sensation disappeared in all 4 patients reporting that concern; only the patient who refused OMT had documentation of continued mass sensation.

Only 3 patients (25\%) received pain medication prescriptions from or at the recommendation of the GS service. One was prescribed pain medication after cholecystectomy; 1 had been previously prescribed pain medication and the GS service recommended continuation. These 2 patients received opioids. The third patient was prescribed ibuprofen by the emergency department for modulation of rib pain.

Details about rib SD, OMT performed by the GS service, OMT complications and 6-month musculoskeletal and other follow-up details are summarized in

Table 2. The 6-month follow-up data from patient 12 was not included because the patient encountered the GS service 1 month before to IRB approval of this study only had 1-month follow-up data available. For clarity, rib SD is described using language adapted from Foundations for Osteopathic Medicine ${ }^{7}$ and Glossary of Osteopathic Terminology. ${ }^{8}$

Unilateral lower rib inhalation restriction was the most common finding (9 [75\%]). Six patients had lower rib anterior displacement. One patient had exhalation restriction and was the only patient who had direct chest trauma and rib fractures years before the GS service. One patient had extra-anatomic lateral displacement and was the only patient to have undergone preencounter thoracic operation. This displacement seemed to be the result of operative trauma (ie, forcing the rib beyond the anatomic barrier). One patient had xiphoid posterior displacement secondary to large breast size and tightness of her brassiere.

OMT techniques varied per patient, but myofascial release, counterstrain, and balanced ligamentous tension were the most frequent modalities. No highvelocity, low-amplitude techniques were used, and OMT was universally described by the physicians as "gentle." Treatments emphasized the restoration of physiologic diaphragmatic motion through diaphragm release techniques and counterstrain to address tenderpoints which were localized in 9 patients.

The length of the OMT session was not documented for 4 patients. Among the patients who did have the length of the OMT session documented, the time ranged from 5 to 30 minutes with a median of 10 minutes and mean (SD) 12.7 (9.05) minutes. OMT was used to manage any identified anatomical area of SD but was primarily focused on rib SD.

Over the course of 6 months, 3 patients had OMM/ NMM consultant follow-up with a range of 2 to 5 additional OMT sessions. None of the patients had physical therapy or followed up with a musculoskeletal specialist. Patient 3, who had a cholecystectomy, was readmitted for oral intolerance, retained a common bile duct stone, and had a routine endoscopic retrograde cholangiopancreatography. Throughout the perioperative course, patient 3 denied the recurrence of rib SD. The patient who had perioperative hematoma continued to have rib pain that was documented by the breast 


\section{Table 2.}

Rib SD Diagnosis and Technique of OMT for Patients Receiving GS Service at St Barnabas Hospital Health System Between February 1, 2016 to January 31, 2019 ( $N=12)$

\begin{tabular}{|c|c|c|c|c|c|}
\hline Patient & Rib SD & $\begin{array}{l}\text { OMT technique } \\
\text { performed } \\
\text { (total time) }\end{array}$ & $\begin{array}{c}\text { OMT } \\
\text { complications }\end{array}$ & $\begin{array}{l}\text { Musculoskeletal } \\
\text { consultant follow-up }\end{array}$ & Other follow-up \\
\hline 1 & $\begin{array}{l}\text { - Right ribs } 10-12 \\
\text { inhalation restriction } \\
\text { - Rib } 10 \text { anterior } \\
\text { displacement }\end{array}$ & $\begin{array}{l}\text { MFR, BLT, ST (10 } \\
\text { minutes) }\end{array}$ & None & None & None \\
\hline 2 & $\begin{array}{l}\text { - Left ribs } 11-12 \text { inhalation } \\
\text { restriction }\end{array}$ & $\begin{array}{l}\text { MFR, CS (not } \\
\text { documented) }\end{array}$ & None & None & None \\
\hline 3 & $\begin{array}{l}- \text { Right ribs } 11-12 \\
\text { inhalation restriction }\end{array}$ & $\begin{array}{l}\text { MFR, RR, BLT, } \\
\text { ME, CS (20 } \\
\text { minutes) }\end{array}$ & None & $\begin{array}{l}\text { OMM/NMM consultant inpatient } \\
\text { treatment } \mathrm{x} 2 \text { with documented } \\
\text { improvement }\end{array}$ & $\begin{array}{c}\text { Readmission for retained } \\
\text { common bile duct stone } \\
\text { without recurrence of rib } \\
\text { SD }\end{array}$ \\
\hline 4 & $\begin{array}{l}\text { - Left ribs } 7-12 \text { inhalation } \\
\text { restriction } \\
\text { - Left ribs 7-10 anterior } \\
\text { displacement } \\
\text { - Left rib } 7 \text { extra-anatomic } \\
\text { lateral displacement }\end{array}$ & $\begin{array}{l}\text { MFR, BLT, ME, CS } \\
\text { (30 minutes) }\end{array}$ & None & $\begin{array}{l}\text { OMM/NMM consultant } \\
\text { outpatient treatments } x 5 \text { with } \\
\text { documented improvement }\end{array}$ & None \\
\hline 5 & $\begin{array}{l}\text { - Left ribs 8-12 inhalation } \\
\text { restriction } \\
\text { - Left ribs 7-10 anterior } \\
\text { displacement }\end{array}$ & $\begin{array}{l}\text { MFR, BLT, ME, CS } \\
\text { (not documented) }\end{array}$ & None & None & None \\
\hline 6 & $\begin{array}{l}\text { - Right ribs 5-6 inhalation } \\
\text { restriction }\end{array}$ & $\begin{array}{l}\text { MFR, BLT, ME, CS } \\
\text { (not documented) }\end{array}$ & None & None & $\begin{array}{l}\text { Rib pain noted to have } \\
\text { recurred on 1-month } \\
\text { follow-up with breast } \\
\text { surgeon }\end{array}$ \\
\hline 7 & $\begin{array}{l}\text { - Right ribs 7-12 inhalation } \\
\text { restriction } \\
\text { - Right ribs 7-10 anterior } \\
\text { displacement }\end{array}$ & $\begin{array}{l}\text { MFR, RR, BLT, } \\
\text { ME, CS (not } \\
\text { documented) }\end{array}$ & None & $\begin{array}{l}\text { OMM/NMM consultant inpatient } \\
\text { treatment } \mathrm{x} 2 \text { with documented } \\
\text { improvement }\end{array}$ & None \\
\hline 8 & $\begin{array}{l}\text { - Right ribs 6-9 inhalation } \\
\text { restriction }\end{array}$ & $\begin{array}{l}\text { MFR, RR, BLT (5 } \\
\text { minutes) }\end{array}$ & None & None & None \\
\hline 9 & $\begin{array}{l}\text { - Left ribs } 10-12 \text { inhalation } \\
\text { restriction } \\
\text { - Left rib } 10 \text { anterior } \\
\text { displacement }\end{array}$ & Not performed. & N/A & None & None \\
\hline 10 & $\begin{array}{l}\text { - Left ribs } 7-12 \text { inhalation } \\
\text { restriction } \\
\text { - Left rib 9-10 anterior } \\
\text { displacement }\end{array}$ & $\begin{array}{l}\text { MFR, CS (10 } \\
\text { minutes) }\end{array}$ & None & None & $\begin{array}{l}\text { COPD exacerbation after } \\
\text { five months resulted in } \\
\text { recurrent but less } \\
\text { prominent pain }\end{array}$ \\
\hline 11 & $\begin{array}{l}\text { - Right ribs 7-9 exhalation } \\
\text { restriction and } \\
\text { anteroposterior } \\
\text { compression }\end{array}$ & $\begin{array}{l}\text { MFR, RR, BLT, CS } \\
\text { (7 minutes) }\end{array}$ & None & None & None \\
\hline
\end{tabular}


Table 2 (continued).

Rib SD Diagnosis and Technique of OMT for Patients Receiving GS Service at St Barnabas Hospital Health System Between February 1, 2016 to January 31, 2019 ( $N=12)$

\begin{tabular}{|c|c|c|c|c|c|}
\hline Patient & Rib SD & $\begin{array}{c}\text { OMT technique } \\
\text { performed } \\
\text { (total time) }\end{array}$ & $\begin{array}{c}\text { OMT } \\
\text { complications }\end{array}$ & $\begin{array}{l}\text { Musculoskeletal } \\
\text { consultant follow-up }\end{array}$ & Other follow-up \\
\hline 12 & $\begin{array}{l}\text { - Left rib 6-7 } \\
\text { anteroposterior } \\
\text { compression } \\
\text { - Xiphoid posterior } \\
\text { displacement }\end{array}$ & $\begin{array}{l}\text { MFR, RR, BLT, CS } \\
\text { (7 minutes) }\end{array}$ & None & None & $\begin{array}{c}\text { Planning for bariatric } \\
\text { surgery }\end{array}$ \\
\hline
\end{tabular}

Abbreviations: BLT, balanced ligamentous tension; COPD, chronic obstructive pulmonary disease; CS, counterstrain; ME, muscle energy; MFR, myofascial release; OMM/NMM, osteopathic manipulative medicine/neuromusculoskeletal medicine; OMT, osteopathic manipulative treatment; RR, rib-raising; ST, soft tissue; $\mathrm{SD}$, somatic dysfunction.

surgeon 1 month after GS service. The patient was referred to OMM/NMM but did not follow-up with this service. Patient 6 experienced a mild recurrence of rib SD symptoms after a chronic obstructive pulmonary disease exacerbation 5 months after GS service and did not receive OMT. One patient, whose weight was associated with their chief concern, was in the planning process for bariatric surgery at the 6-month follow-up.

\section{Discussion}

Referrals to GS may be triggered by rib SD with or without imaging studies that are suggestive of underlying GS operative indication. In our cohort, only 1 patient required a GS operation related to their chief complaint while the rest received OMT and had no operation.

By examining a single anatomical area of SD using specific International Statistical Classification of Diseases and Health Related Problems codes, we detailed the characteristics of GS services involving rib SD and OMT. This approach could be beneficial for further GS or surgical subspecialty studies (eg, OMT targeting the digestive tract after exploratory laparotomy or thoracic OMT after chest operation). OMT could also be used for the management of a broader range of SD in the surgical setting. ${ }^{1,2}$ More focused and detailed descriptions of OMT approaches used in a nonmusculoskeletal specialty setting may better inform surgeons who are unfamiliar with OMT. ${ }^{1,2}$

We examined OMT use in outpatient and inpatient clinical settings. Previous work has examined OMT performed exclusively in the outpatient ${ }^{9}$ or inpatient $^{10}$ settings. General surgeons encounter patients in both outpatient and inpatient settings and throughout the perioperative period; therefore, a study of OMT spanning these settings would best illustrate the use of OMT for GS services.

While pain management has been considered a benefit of OMT for quite some time, ${ }^{11,12}$ the benefits of OMT for visceral function are still contentious, ${ }^{13,14}$ and further study is required. In our study, P\&T was resolved or improved, and follow-up demonstrated either no recurrence, attenuated recurrence, or continued improvement after OMT. Opioid pain medications were used sparingly by the GS service, but this study was limited in its scope and did not show an obvious correlation of the use of OMT and minimal opiate requirements.

Our study provides minimal insight into interactions between OMT and visceral function; however, we note that in the patient who was treated for both rib SD and operative GS disease, symptoms resolved by a combination of both OMT and operative intervention. Other studies $^{2,15}$ have noted a cumulative benefit of OMT and standard care. ${ }^{2,15}$ 


\section{Limitations}

Our study has several limitations, including the small sample size, the retrospective and single-center design, and the descriptive data that lacks a comparator. However, the details are meant to support future scientific work in the GS setting, and at minimum, suggest surgical care providers may consider OMT as an adjunct to standard care.

During analysis, we noted routine encounters between the OMM/NMM service and GS patients for treatment of rib SD. Therefore, the presence of an OMM/NMM service may dilute initial use of OMT by trained general surgeons. Finally, follow-up may have been incomplete as patients in New York City have access to many nearby centers for outpatient and inpatient care. Patients in our cohort may have received follow-up for which we do not have complete access to data.

\section{Conclusions}

Rib somatic dysfunction may contribute to patient referral to a general surgery service, and OMT may help provide optimal surgical care. Further study into somatic dysfunction among general surgical patients is warranted.

\section{Author Contributions}

All authors provided substantial contributions to conception and design, acquisition of data, or analysis and interpretation of data; all authors drafted the article or revised it critically for important intellectual content; all authors gave final approval of the version of the article to be published; and all authors agree to be accountable for all aspects of the work in ensuring that questions related to the accuracy or integrity of any part of the work are appropriately investigated and resolved.

\section{References}

1. Sposato NS, Bjerså K. Osteopathic manipulative treatment in surgical care: short review of research publications in osteopathic journals during the period 1990 to 2017. J Evid Based Integr Med. 2018;23:2515690X18767671. doi:10.1177/2515690X18767671
2. Racca V, Bordoni B, Castiglioni P, Modica M, Ferratini M. Osteopathic manipulative treatment improves heart surgery outcomes: a randomized controlled trial. Ann Thorac Surg. 2017;104(1):145-152. doi:10.1016/j.athoracsur.2016.09.110

3. Wax CM, Abend DS, Pearson PH. Chest pain and the role of somatic dysfunction. J Am Osteopath Assoc. 1997;97(6):347-352, 355. doi:10.7556/jaoa.1997.97.6.347

4. Udermann BE, Cavanaugh DG, Gibson MH, Doberstein ST, Mayer JM, Murray SR. Slipping rib syndrome in a collegiate swimmer: a case report. J Athl Train. 2005;40(2):120-122.

5. Pierce-Talsma S, Talsma J, Ferrill H. An osteopathic approach to rib somatic dysfunction in respiratory disorders. J Am Osteopath Assoc. 2018;118(10):e94-e95. doi:10.7556/jaoa.2018.152

6. Licciardone JC, Kearns $\mathrm{CM}$, King $\mathrm{HH}$, et al. Somatic dysfunction and use of osteopathic manual treatment techniques during ambulatory medical care visits: a CONCORD-PBRN study. J Am Osteopath Assoc. 2014;114(5):344-354. doi:10.7556/jaoa.2014.072

7. Hruby RJ. Thoracic region and rib cage. Chila AG, ed. Foundations for Osteopathic Medicine. Lippincott Williams \& Wilkins; 2011.

8. Glossary of Osteopathic Terminology. American Association of Colleges of Osteopathic Medicine; 2011. https://www.aacom.org/docs/ default-source/insideome/got2011ed.pdf. Accessed September 25, 2019

9. Licciardone JC, Nelson KE, Glonek T, Sleszynski SL, Cruser DA. Osteopathic manipulative treatment of somatic dysfunction among patients in the family practice clinic setting: a retrospective analysis. J Am Osteopath Assoc. 2005;105(12):537-544.

10. Snider KT, Snider EJ, DeGooyer BR, Bukowski AM, Fleming RK, Johnson JC. Retrospective medical record review of an osteopathic manipulative medicine hospital consultation service. J Am Osteopath Assoc. 2013;113(10):754-767. doi:10.7556/ jaoa.2013.045

11. Kuchera ML. Osteopathic manipulative medicine considerations in patients with chronic pain. J Am Osteopath Assoc. 2005;105(9 suppl 4):S29-S36.

12. Slattengren AH, Nissly T, Blustin J, Bader A, Westfall E. Best uses of osteopathic manipulation. J Fam Pract. 2017;66(12):743-747.

13. Nansel D, Szlazak M. Somatic dysfunction and the phenomenon of visceral disease simulation: a probable explanation for the apparent effectiveness of somatic therapy in patients presumed to be suffering from true visceral disease. J Manipulative Physiol Ther. 1995;18 (6):379-397.

14. Müller A, Franke H, Resch KL, Fryer G. Effectiveness of osteopathic manipulative therapy for managing symptoms of irritable bowel syndrome: a systematic review. J Am Osteopath Assoc. 2014;114 (6):470-479. doi:10.7556/jaoa.2014.098

15. Arienti C, Daccò S, Piccolo I, Redaelli T. Osteopathic manipulative treatment is effective on pain control associated to spinal cord injury. Spinal Cord. 2011;49(4):515-519. doi:10.1038/sc.2010.170

(c) 2020 American Osteopathic Association 